\title{
Beekeeping practice: effects of Apis mellifera virgin queen management on ovary development
}

\author{
Bruno Berger, Silvana Beani Poiani, Carminda da Cruz-Landim \\ Departamento de Biologia, Instituto de Biociências de Rio Claro, Universidade Estadual Paulista - UNESP, Av. 24 A, \\ 1515, Bela Vista, 13.506-900, Rio Claro, São Paulo, Brazil
}

Received 24 June 2015 - Revised 2 October 2015 - Accepted 23 October 2015

\begin{abstract}
Newly emerged virgin queens are frequently imprisoned in cages either inside or outside of colonies before delivery to a new hive. Ovary integrity and proper functioning is the primary factor in a queen's success as the colony mother. In this work, histological studies on ovaries are used to evaluate the effect of virgin queen imprisonment both out and inside the colony. The results show that the ovarian follicles of virgin queens maintained out of the colony advance only until the beginning of differentiation of oocytes and nurse cells, the vitellarium does not differentiate, and cell death is observed. For virgin queens caged inside a colony, oogenesis progresses until nurse cell and oocyte differentiation is completed, and the vitellarium shows initial differentiation. The results suggest that the best method for a head start of a queen's fertility is to maintain her inside the colony until introduction into a new hive.
\end{abstract}

apiculture / caged queen / cell death / egg production / histology

\section{INTRODUCTION}

Over 25,000 species of bees are found in the world and those insects are the most effective pollinators of crops and natural flora that contribute to plant biodiversity. They are reported to pollinate over $70 \%$ of the world's cultivated crops. According to Kenmore and Krell (1998), $15 \%$ of the hundred principal crops are pollinated by domestic bees (i.e. manageable species e.g. hive-kept species of honeybees, bumblebees, alfalfa bees, etc.), while at least $80 \%$ are pollinated by wild bees.

Honey bees (Apis mellifera Linné, 1758) are the main pollinators and their value in managing pollination has been estimated by services in the United States to be 14 billion dollars per year (Delaplane and Mayer 2000; Morse and

Corresponding author: S. Poiani,

silbeani@gmail.com

Manuscript editor: Klaus Hartfelder
Calderone 2000). Willians (1995) suggested that one-third of the food production for human and animal consumption depends directly or indirectly on bee pollination.

Beekeeping productivity depends primarily on the queen's egg laying ability, resulting in the production of workers that gather food, build the nest and care for the queen and her offspring. A common beekeeping practice is the production of selected virgin and mated queens for sale. Artificially produced queens are confined in individual boxes out of colonies with a certain number of workers, or kept in orphaned colonies until they are sent to the future destination. This practice is known as queen banking. Whereas queen banking inside colonies permits ample contact between the caged queen and the colony environment, this is not so when queens are banked in boxes outside of colonies.

Using such queen banking techniques, a large number of virgin queens can be maintained until freed for natural nuptial flight or artificial fertilization before a colony is ready to receive a new 
queen. Although studies suggest that this technique facilitates apicultural work, management flexibility and efficiency in producing queens, it does not generate the same results as those achieved with queens that mate freely (Cobey 2007).

A. mellifera is an advanced eusocial bee species with a matriarchal social organization and a reproductive division of labor between the colony females. The queen is the female with a long life that is responsible for egg production (reproduction), and numerous short-lived females, the workers, responsible for all services necessary for colony survival. Honey bees have meroistic polytrophic ovaries comprising hundreds of ovarioles (Snodgrass 1956; Wilson 1976). Each ovariole of the mature ovary consists of a terminal filament that accommodates oogonia, a germarium where the mitotic divisions for follicle formation occur, and the vitellarium containing growing follicles consisting of an oocyte and nurse cell chamber, both surrounded by follicle epithelial cells (Cruz-Landim 2009). According to Snodgrass (1956), A. mellifera queens can lay up to 3,000 eggs per day under optimal conditions.

Given the importance of the ovary for the success of the hive, the purpose of the present work was to evaluate the ovary conditions of A. mellifera queens by comparing the effects of different types of queen caging (out and inside the colony), on oogenesis and ovary development.

\section{MATERIAL AND METHODS}

\subsection{Material}

Virgin queens were artificially produced in the apiary at the Departamento de Biologia, Instituto de Biociências de Rio Claro (UNESP; Rio Claro, São Paulo, Brazil) following the method of Doolittle (1899) and using larvae from the same colony.

\subsection{Methods}

\subsubsection{Virgin queens}

Thirty newly emerged artificially produced queens were individually imprisoned with six nurse workers in $5 \times 5 \times 2 \mathrm{~cm}$ wood boxes containing candy ad libitum .
The workers were changed every two days. The boxes containing the bees were maintained for 15 days outside of the colony in an incubator where the temperature was kept at a constant $32{ }^{\circ} \mathrm{C}$ and the relative humidity was $70 \%$.

Equally, 10 other artificially produced queens were individually imprisoned in $5 \times 5 \times 2 \mathrm{~cm}$ wooden boxes and maintained for 15 days inside small orphaned hives. The hives consisted of two brood combs with pollen and honey and a population of workers of several age classes. The boxes were closed by a wire mesh through which the workers could contact and feed the queen.

\subsubsection{Mated queens}

Ten laying queens were captured from strong hives, and their ovaries were dissected and fixed for morphological analysis.

\subsubsection{Ovary preparation for light microscopy (LM)}

Ovaries from 10 individuals from each group were dissected and fixed in $4 \%$ paraformaldehyde in $0.1 \mathrm{M}$ sodium phosphate buffer, $\mathrm{pH} 7.4$ for 24 hours. After fixing, the ovaries were dehydrated in a graded ethanol series, ending with $95 \%$ ethanol, embedded and blocked in Histo-Resin (Leica) in accordance with the manufacturer's recommendations. Five-micrometerthick sections were cut using a Leica RM 2145 microtome, placed on histological slides, stained with $1 \%$ toluidine blue at $\mathrm{pH} 4.0$, and hematoxylin/eosin. The sections were then photographed using a Leica photomicroscope and Leica QWin software. Digital corrections of contrast, brightness and dust/ imperfections removal were made on ADOBE Photoshop CS software and the figures were composed using Corel Draw X7 software.

\section{RESULTS}

\subsection{Virgin queens maintained inside hives}

In newly emerged queens, almost the entire ovariole consisted of terminal filament, and the basal germarium was poorly developed. A few days after the queens emerged, the germarium came to be more clearly visible in virgin queens kept inside the colony. This extended portion 
seems a precursor of the vitellarium region. The 15-day-old virgin queens maintained caged inside orphaned colonies presented ovarioles of different developmental and conservation stages (Figure 1a). The terminal filaments were formed by stacks of polyhedral cells, which in longitudinal sections appeared as rectangular single cell rows (Figure 1b). At the transition between the terminal filament and the germarium, the cells acquired a pyramidal shape, with an enlarged base at the tunica propria and the apex tapering to the ovariole center (Figure 1b).

In the ovary of these queens, an early differentiation stage of a germarium and vitellarium was visible in some ovarioles (Figure 1d). In some regions of the germarium, cells in early oogenesis were present, represented by cysts of undifferentiated cystocytes and cysts in which some cystocytes had begun to differentiate into oocytes (Figure 1c). At a more basal section of the ovarioles, some cysts were beginning to acquire a prefollicular morphology, with cystocytes starting to differentiate into nurse cells and oocytes (Figure 1c), indicating the beginning of a vitellarium differentiation. In an even more basal section of some ovarioles, separation of the nurse and oocytic chambers were clearly visible in certain initial follicles (Figure 1d). Cell death was rarely observed during ovary development in this type of queen banking.

\subsection{Virgin queens maintained outside the colony}

The ovaries of virgin queens maintained in boxes outside the colony for 15 days presented an ovariole morphology similar to that of the queens maintained inside the hives (Figure 2). However, the portion of the ovariole occupied by the germarium was larger, and although cystocyte differentiation into nurse cells and oocytes could be seen to initiate at the base of some ovarioles, follicle differentiation was not observed (Figure 2a). The ovarioles showed early differentiation of oocytes and nurse cells (Figure 2b), and in certain regions of the ovarioles, tissue disorganization was frequently observed (Figure 2c). Cell
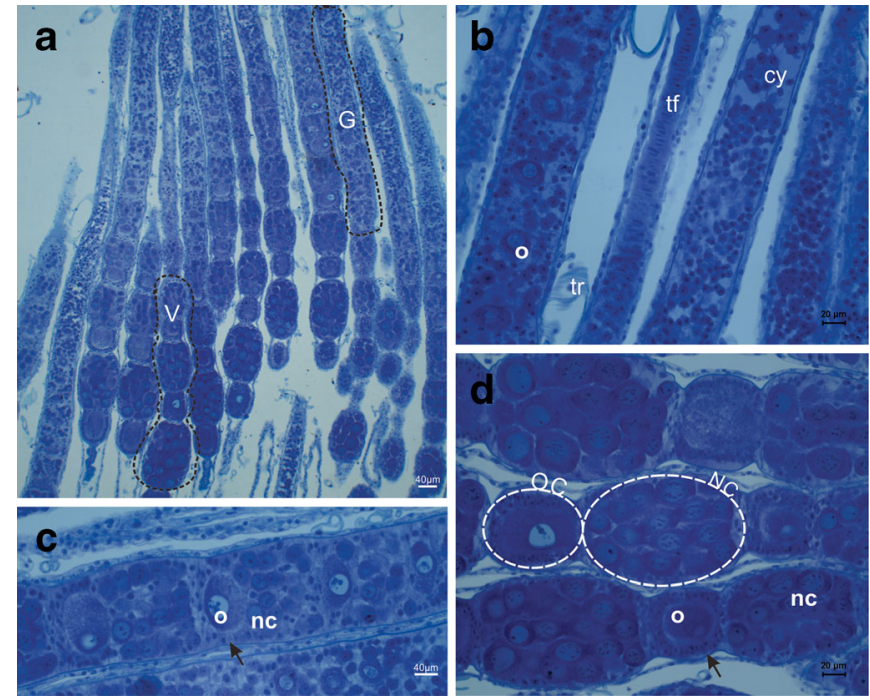

Figure 1. Ovarioles of 15-day-old virgin queens of Apis mellifera, maintained caged inside the hive; a . The ovaries have well-preserved ovarioles where the germarium (G) and vitellarium (V) are well differentiated; $\mathbf{b}$. Detail of the terminal filament (tf) to germarium transition region showing oocytes (o) and cystocytes (cy). Oocyte and cystocyte indications are in different ovarioles .tr- trachea; $\mathbf{c}$. Transition to the vitellarium showing the beginning of follicles formation by separation between oocyte (o) and nurse cells (nc) and differentiation of the follicular cell (arrow) envelope of the oocyte; $\mathbf{d}$. Vitellarium showing follicles with well differentiated oocytic chambers (OC) containing an oocyte (o) and nurse cell chamber (NC) containing nurse cell (nc). 


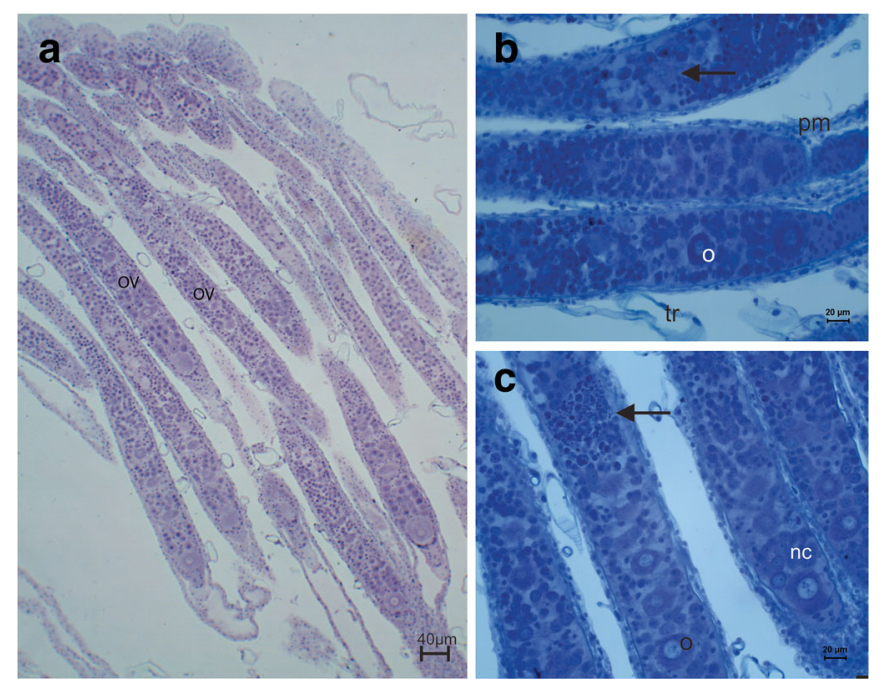

Figure 2. Ovarioles of fifteen-day-old virgin queens of Apis mellifera, maintained in small boxes outside the colony; a. General view of ovarioles (OV) showing no follicle differentiation; $\mathbf{b}$ and $\mathbf{c}$. The ovarioles show early differentiation of oocytes (o) and nurse cells (nc) although without differentiation into follicles. Regions of cell death are present (arrows). pm- peritoneal membrane.

death primarily occured in ovariole regions just prior to the differentiation of different cell types.

\subsection{Mated queens}

Mated queens showed the greatest progress in oogenesis. The ovarioles of these queens showed well-defined ovariole components, where terminal filament, germarium and vitellarium were completely differentiated. All stages of oogenesis were observed, including undifferentiated cells in the terminal filament, cysts containing cystocytes in early stages of differentiation in the germarium, fully differentiated follicles, showing nurse and oocytic chamber formation in the previtellogenic phase, and fully mature oocytes (Figure 3).

\section{DISCUSSION}

An important and common beekeeping practice is the artificial production of selected virgin and mated queens for sale. The procedure usually consists in confining queens in individual boxes together with a few workers outside of hives until the queens are sent to their future destination. The conditions of caged queens, both inside or outside the colony, can affect ovary development and potentially compromise the success of the future hive that will receive the queen.

The ovary morphology of newly emerged virgin queens of $A$. mellifera presents a short differentiated germarium at the base of the ovariole, where proliferating cystocytes are present. In 3day-old virgin queens, cysts of cystocytes, which are organized in rosettes, are present in the ovarioles; in 5-day-old, queens oogenesis has already advanced to cysts, wherein germ cells have differentiated into oocytes and future nurse cells (Berger and Abdalla 2005; Berger and CruzLandim 2009; Berger et al. 2005; Patrício and Cruz-Landim 2002). However, the morphology of the ovary begins to change according to the time that the queen remains caged without mating. The results of our study showed that the sequence of ovarian development in virgin queens caged for 15 days inside or outside the hive presents differences between the two types of queen banking. When queens were maintained inside an orphaned colony, i.e., within the social context, ovarian development progressed to a more advanced stage and showed less disorganization and cell death compared with virgin queens imprisoned in boxes outside the colony. The cell death observed in 

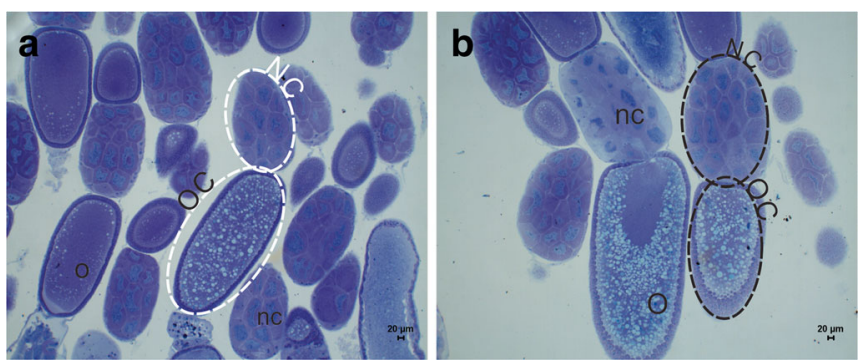

Figure 3. Ovaries of fifteen-day-old mated Apis mellifera queens; $\mathrm{a}$ and $\mathrm{b}$. Note the full ovarian development and clear differentiation of the nurse and oocytic chambers. o-oocyte, nc- nurse cell, NC- Nurse chamber, OC- Oocytic chamber.

ovarioles of virgin queens caged outside the colony was in regions were cell differentiation occurs, and this may compromise the future nurse cells.

Given the conditions for colony organization, three types of controls can influence queen ovarian function: an intrinsic control due to genetics and physiology; a colony environment control derived from interactions between castes and colony conditions, such as colony age demography, the number of cells available for egg laying and available food; and the beekeeper's management practice, such as fumigation that exposes bees to $\mathrm{CO}_{2}$ that has an effect on the ovary of workers and queens (Berger and Cruz-Landim 2012; Berger et al. 2015; Butler and Simpson 1965; CruzLandim et al. 2006; Hamilton 1964; Hartfelder 2000; Page and Ericksons 1988; Patrício and Cruz-Landim 2003). Although Cobey (2007) found that the colony environment is indispensable for the start of oogenesis in the ovaries, the results herein showed that even in queens maintained outside of the colony environment, follicle differentiation can advance until separation of the oocyte and pre-nurse cells, which is just one step short of the ovarian development seen in queens maintained inside a colony. Therefore, the colonial environment can facilitate ovarian development, and its absence may delay ovarian development and lead to more extensive structural disorganization of the ovarioles and cell death.

Another important point to be considered and directly related to ovary development success is the mating time and completion of oogenesis that only proceeds after mating. Queen maintenance for sale frequently retards mating time, and even for virgin queens that were kept inside the colony and within social context can have the integrity of ovarian function affected. Under natural conditions, the queens perform the mating flight at approximately 6-8 days of age, which is when oogenesis has progressed to the point where some cystocytes in ovarian cysts are ready to undergo meiosis, i.e., they have become a primary oocyte (Cruz-Landim 2009). If mating is delayed, the germ cells within the germarium disorganize and cell death occurs (Berger and Cruz-Landim 2012; Berger et al. 2005). In several insects, mating is the primary factor that triggers oocyte ripening in the ovary, indicating the presence of factors in seminal fluid that trigger oogenesis (Ando et al. 1996; Coffelt and Vick 1987; Fan et al. 1999; Foster 1993; Giebultowicz et al. 1991; Rafaeli and Gileadi 1995; Raina et al. 1994; Shorey et al. 1968; Webster and Carde 1984). Nonetheless, when analyzing mucus gland secretions, which are introduced with semen into the genital tract of honey bee queens, Colonello and Hartfelder (2003) did not find evidence that drone accessory gland proteins are necessary for ovarian development in A. mellifera.

\section{CONCLUSIONS}

Our results are a contribution to the knowledge of beekeeping practice, showing that social interaction is important for ovarian development in A. mellifera queens. We found that the best method for queen banking and a head start for queen fertility is to maintain her inside the colony until introduction into a new hive. Nonethless, caging 
time also needs to be taken into account, as this may affect queen fertility.

\section{ACKNOWLEDGMENTS}

The present work was financed by the Brazilian Research Agency FAPESP (Fundação de Amparo à Pesquisa do Estado de São Paulo), Process no. 05/ 53999-9 and no. 2009/17218-3.

Pratique apicole: effets du mode d'isolement des reines vierges d'Apis mellifera sur leur développement ovarien

apiculture / reine en cage / mort cellulaire / production d'oeufs / histologie

Beitrag zur Praxis der Bienenhaltung: Auswirkung der Haltungsweise von Apis mellifera Jungköniginnen auf deren Ovarentwicklung

Bienenhaltung / gekäfigte Königinnen / Zelltod / Eiproduktion / Histologie

\section{REFERENCES}

Ando, T., Kasuga, K., Yajima, Y., Katoaka, H., Suzuki, A. (1996) Termination of sex pheromone production in mated females of silkworm moth. Arch. Insect Biochem. Physiol. 31 (2), 207-218

Berger, B., Abdalla, F.C. (2005) Programmed germ cell differentiation during ovary stages of oogenesis in caged virgin and fecundated queens of Apis mellifera Linné, 1758 (Hymenoptera, Apini). Braz. J. Morphol. Sci. $22(1), 1-4$

Berger, B., Cruz-Landim, C. (2009) Ultrastructural analysis of the effect of mating delay on cell death in the ovaries of virgin honey bee (Apis mellifera L.) queens. J. Apic. Res. 48(1), 60-66

Berger, B., Cruz-Landim, C. (2012) Ovarian ultrastructure in virgin queens of Apis mellifera L. narcotized by $\mathrm{CO}_{2}$. Micron $43(7), 832-838$

Berger, B., Abdalla, F.C., Cruz-Landim, C. (2005) Effect of Narcosis with $\mathrm{CO}_{2}$ on the Ovarian Development in Queens of Apis mellifera Linné, 1785 (Hymenoptera, Apini). Sociobiology 45(2), 261-271

Berger, B., Poiani, S.B., Roat, T.C., Cruz-Landim, C. (2015) Ovary development in honeybee (Apis mellifera L.) workers under $\mathrm{CO}_{2}$ narcosis, caged outside of the colony. J. Apic. Sci. 59(1), 51-58

Butler, C. G., Simpson, J. (1965) Pheromones of the honeybees (Apis mellifera L.). An olfactory pheromone from the Koschewnikow gland of the queen. Scientific Studies of University Libice, Czechoslovakia 4, 33-36

Cobey, S.W. (2007) Comparison studies of instrumentally inseminated and naturally mated honey bee queens and factors affecting their performance. Apidologie 38(4), 390-410

Coffelt, J.A., Vick, K.W. (1987) Sex pheromone of Ephestia cautella (Walker) (Lepidoptera: Pyralidae): influence of mating on pheromone titer and release rate. J. Stored Prod. Res. 23 (2), 119-123

Colonello, N.A., Hartfelder, K. (2003) Protein content and pattern during mucus gland maturation and its ecdysteroid control in honey bee drones. Apidologie 34 (3), 257-267

Cruz-Landim, C. (2009) Morfologia e função de sistemas. Editora Unesp, São Paulo

Cruz-Landim, C., Patricio, K., Antonialli Junior, W.F. (2006) Cell death and ovarian development in highly eusocial bees (Hymenoptera, Apidae): caste differentiation and worker egg laying. Braz. J. Morphol Sci. $23(1), 27-42$

Delaplane, K.S., Mayer, D.F. (2000) Crop pollination by bees. CABI Publishing, Wallingford

Doolittle, G.M. (1899) Doolittle queen-rearing methods. Am. Bee J. 39, 435-436

Fan, Y.L., Rafaeli, A., Gileadi, C., Kubli, E., Applebaum, S.W. (1999) Drosophila melanogaster sex peptide stimulates juvenile hormone synthesis and depresses sex pheromone production in Helicoverpa armigera . J. Insect Physiol. 45 (2), 127-133

Foster, S.P. (1993) Neural inactivation of sex pheromone production in mated light brown apple moths, Epiphyas postvittata (Walker). J. Insect Physiol. 39 (3), 267-273

Giebultowicz, J.M., Raina, A.K., Uebel, E.C., Ridgway, R.L. (1991) Two-step regulation of sex-pheromone decline in mated gypsy moth females. Arch. Insect Biochem. Physiol. 16 (2), 95-105

Hamilton, W.D. (1964) The genetical evolution of social behavior, I and II. J. Theor. Biol. 7 (1), 1-52

Hartfelder, K. (2000) Insect juvenile hormone: from "status quo" to high society. Braz. J. Med. Biol. Res. 33 (2), 157-177

Kenmore, P., Krell, R. (1998) Global perspectives on pollination in agriculture and agroecosystem management. International Workshop on the Conservation and Sustainable Use of Pollinators in Agriculture, with Emphasis on Bees. 7-9

Morse, R.A., Calderone, N.W. (2000) The value of honeybees as pollinators of U.S. crops in 2000. Bee Culture 128, $1-15$

Page, R.E., Erickson, E.H. (1988) Reproduction by worker honey bee (Apis mellifera). Behav. Ecol. Sociobiol. $23(2), 117-126$

Patrício, K., Cruz-Landim, C. (2002) Mating influence in the ovary differentiation in adult queens of Apis mellifera (Hymenoptera, Apidae). Braz. J. Biol. 62 (4a), 641-649 
Patrício, K., Cruz-Landim, C. (2003) Apis mellifera (Hymenoptera, Apini) ovary development in queens and workers from queenright and queenless colonies. Sociobiology 42, 771-779

Rafaeli, A., Gileadi, C. (1995) Factors affecting pheromone production in the stored product moth, Plodia interpunctella: a preliminary study. J. Stored Prod. Res. 31 (3), 243-247

Raina, A.K., Kingan, T.G., Giebultowicz, J.M. (1994) Mating-induced loss of sex pheromone and sexual receptivity in insects with emphasis on Helicoverpa zea and Lymantria dispar. Arch. Insect Biochem. Physiol. 25(4), 317-327

Shorey, H.H., McFarland, S.U., Gaston, L.K. (1968) Sex pheromones of noctuid moths. XIII. Changes in pheromone quantity as related to reproductive age and mating history in females in seven species of Noctuidae (Lepidoptera). Ann. Entomol. Soc. Am. 61 (2), 372-376

Snodgrass, R.E. (1956) Anatomy of the honey bee. Comstock Publ. Ass. Cornell Univ. Press, Ithaca

Webster, R.P., Carde, R.T. (1984) The effects of mating, exogenous juvenile hormone and a juvenile hormone analogue on pheromone titter, calling and oviposition in the omnivorous leaf roller moth (Platynota stultana ). J. Insect Physiol. 30, 113-118

Willians, C.S. (1995) Conserving Europe's bees: why all the buzz? Trends Ecol. Evol. 10(8), 309-310

Wilson, E.O. (1976) The insect societies. The Belknap Press of Havard University Press, Cambridge 